\title{
Toxicological evaluation of engineered layered double hydroxide nanomaterials to Biomphalaria alexandrina snails: a study on the mechanism of action
}

Heba Abdo ( $\square$ hoba_abdo_2010@yahoo.com )

Beni Suef University Faculty of Science

Amina Mohamed Ibrahim

Theodor Bilharz Research Institute

Taghreed Hussein

National Organization for Drug Control and Research

Fatma Mohamed

Beni Suef University Faculty of Science

\section{Research Article}

Keywords: LDH, Toxicity, B. alexandrina, Biomarker, Commet assay

Posted Date: March 22nd, 2021

DOI: https://doi.org/10.21203/rs.3.rs-297612/v1

License: (c) (i) This work is licensed under a Creative Commons Attribution 4.0 International License.

Read Full License 


\section{Abstract}

Layered double hydroxide (LDH) nanomaterials have recently become immense research area as it is used widely in industries. So, it's chance of their release into natural environment and risk assessment to non-target aquatic invertebrate increasing. So, the present study aimed to synthesize and confirme the crystalline formation of Co-Cd-Fe LDHs and Co-Cd-Fe / $\mathrm{Pbl}_{2}(\mathrm{LDH})$, and then to investigate the toxic impact of the two LDH on the adult freshwater snails (Biomphalaia alexandrina). Results showed that Co$\mathrm{Cd}-\mathrm{Fe} / \mathrm{Pbl}_{2} \mathrm{LDH}$ has more toxic effect to adult Biomphalaria than Co-Cd-Fe LDHs ( $\mathrm{LC}_{50}$ was $56.4 \mathrm{mg} / \mathrm{l}$, $72 \mathrm{~h}$ of exposure). The effect of $\mathrm{LC}_{25}(117.1 \mathrm{mg} / \mathrm{l})$ of Co-Cd-Fe LDHs exposure on the embryo; showed suppression of embryonic development and induced embryo malformation. Also, it showed alterations in the tegmental architectures of the mantle-foot region of $B$. alexandrina snails as declared in scanning electron micrograph. Also, exposure to this sub lethal concentration caused abnormalities in hemocyte shapes and up-regulated IL-2 level in soft tissue. In addition, it decreased levels of non-enzymatic reduced glutathione (GSH), catalase (CAT), superoxide dismutase (SOD), caspase-3 activity and total protein content in significant manner. While, glutathione S-transferase (GST) activity was not affected by LDH exposure. It caused histopathological damages in both the hermaphrodite and digestive glands. Also, it has a genotoxic effect that was confirmed by alkaline comet assay. The results from the present study indicated that LDH has risk assessment on aquatic $B$. alexandrina snails and that it can be used as a biological indicator of water pollution with LDH

\section{Introduction}

Nanomaterials have been applied in many biomedical researches due to their unique optical, electronic and magnetic characteristics. (Bazrafshan et al., 2017; Corsi et al., 2018; Tarafdar et al., 2013). Layered double hydroxide (LDH) is one of two dimensional layered inorganic nanomaterials. It is one of various cheap nanoparticles bearing positive charge (Thomas and Daniel 2019, Qu et al., 2016). Recently, Layered materials have been extensively used in the application of catalysis, polymer nanocomposites and sensors (Zhao et al., 2007; Manzi-Nshuti et al., 2009; Han et al., 2011), in medicine and pharmacy (Ladewig et al., 2009; Choi and Choy, 2011). Additionally, it is used as fertilizers, herbicides, growth regulators and in removing environmental chemical pollution (Li et al., 2016; Peligro et al., 2016; Daniel and Thomas, 2020; Benício et al., 2020). Their unique uses in many applications depending on the host molecule. These have been attributed to their exchange capacity of anionic and capability to accommodate in the interlayer region different types of functional anions/molecules (metals, halocomplexes, polymers, proteins, drugs, etc.). The wide spread utilization of LDHs may lead to increase the chance of their release into the aquatic ecosystem, which has not been investigated. Toxicological evaluation of LDH has been gained environmental and human health care, since it may cause a negative impact to non-target aquatic fauna.

Many articles elucidate the toxicological impact of nanomaterials to aquatic organism such as zooplankton, fish, alage, freshwater rotifers and snails (Zhu et al., 2009; Kim et al., 2012; Myer et al., 2017; 
Long et al., 2012; Martins et al., 2020; Amorim et al., 2019). However, toxicological impact of inorganic nanomaterial (LDH) to snails doesn't study until now.

B. alexandrina snails are widely accepted invertebrate models to study the toxicity and toxico-kinetic of inorganic nanomaterial for aquatic ecosystem (Kaloyianni et al., 2020; Oliveira-Filho et al., 2017). It is the intermediate host of Schistosoma mansoni. it is wildly disseminated throughout tropical and subtropical highly polluted canals and in the Nile River (DeJong et al. 2001). Biomphalaria characterized by their availability, easy way for collection, Acclimate to laboratory conditions, sensitivity to water and chemical pollutant. All the previous characters nominate it to use as laboratory monitoring in ecotoxicological studies and for analyzing multiples biomarkers. (Duft et al., 2007; OECD, 2016; Oliveira-Filho et al., 2017; Ruppert et al., 2017). Many studies in immunology, reproductive and developmental biology used Biomphalaria as paradigm ( Boisseaux et al., 2017; Khangarot and Das, 2010; Pirger et al., 2018). Nanomaterials (NMs) such as carbon nanotubes, silver nanoparticles has potential effects to $B$. alexandrina as conducted in many studies (Moustafa et al. 2018). The toxicity of NMs has been attributed to reactive oxygen species (ROS) generated that subsequently by lipid peroxidation, DNA and protein damage (Caixeta et al. 2020).

The present study focused on the toxicity of LDHs to B. alexandrina, how it affects their biological processes, and to donate well knowledge about biological behavior and risk assessment of Co-Cd-Fe LDHs in aquatic environments.

\section{Material And Method}

\section{Preparation of two types of LDHs:}

\subsection{Co-Cd-Fe LDH}

$\mathrm{NaOH}(5 \mathrm{M})$ was dissolved in $200 \mathrm{~mL}$ of distilled water. Another $200 \mathrm{~mL}$ aqueous solution of $1 \mathrm{Fe}$ $\left(\mathrm{NO}_{3}\right)_{3} \cdot 19 \mathrm{H}_{2} \mathrm{O}(0.1 \mathrm{M}), \mathrm{Co}\left(\mathrm{NO}_{3}\right)_{2} \cdot 16 \mathrm{H}_{2} \mathrm{O}(0.1 \mathrm{M})$, and $\mathrm{Cd}\left(\mathrm{NO}_{3}\right)_{2} \cdot 4 \mathrm{H}_{2} \mathrm{O}(0.1 \mathrm{M})$ was prepared. This later solution was stirred for $24 \mathrm{~h}$. A pH10 of the reaction is adjusted by using sodium hydroxide solution. At $\mathrm{pH}$ 10 , the solution was divided into two solutions; one of them is stirred for $24 \mathrm{~h}$ and the second one is put in the autoclave for $3 \mathrm{~h}$. A washing process using DI water is carried out for the resulting precipitate to reduce the $\mathrm{pH}$ to 7 . Finally, the product is dried at $80^{\circ} \mathrm{C}$ for one day.

\section{$1.2 \mathrm{~T}-\mathrm{LDHs} / \mathrm{Pbl}_{2} \mathrm{NC}$}

In a general synthesis technique, in-situ growth of the metal cations, typically, $\mathrm{NaOH}(5 \mathrm{M})$ in $200 \mathrm{ml}$ of distilled $\mathrm{H}_{2} \mathrm{O}$ is prepared. Another solution of $\mathrm{Fe}\left(\mathrm{NO}_{3}\right)_{3} \cdot 9 \mathrm{H}_{2} \mathrm{O}(0.1 \mathrm{M}), \mathrm{Co}\left(\mathrm{NO}_{3}\right)_{21} \cdot 6 \mathrm{H}_{2} \mathrm{O}(0.1 \mathrm{M})$, $\mathrm{Cd}\left(\mathrm{NO}_{3}\right)_{2} \cdot 4 \mathrm{H}_{2} \mathrm{O}(0.1 \mathrm{M})$, and $2.5 \mathrm{~g} \mathrm{Pbl}_{2}$ was prepared. This later solution was stirred for $24 \mathrm{~h}$. A pH10 of the reaction is adjusted by using the sodium hydroxide solution. After reaching $\mathrm{pH} 10$, the solution was remained under continuous stirring for $24 \mathrm{~h}$. A washing process using DI water is carried out for the 
resulting precipitate to reduce the $\mathrm{pH}$ to 7 . After washing, a drying process is carried out at $80^{\circ} \mathrm{C}$ for one day.

\section{Characterization Of Ldh}

The XRD patterns of , Co-Cd-Fe LDH, and Co-Cd-Fe LDH/Pbl ${ }_{2}$ NC were obtained by Philips1 X Pert 1 -MRD1 $X$-ray diffraction $\left(\lambda_{\text {CuKa }}=0.15418 \mathrm{~nm}\right.$ ). Samples morphology is investigated using a 1 field-emission 1 1scanning electron 11 microscope (FESEM, TEM, Zeiss SUPRA/55VP with GEMINI/ column). (Fourier Transform Infrared Spectroscopy (FTIR) was performed by A Shimadzu1-FTIR-3401-Jasco1 spectrometer to obtain the important functional groups of the samples. Finally, the optical absorbance behaviors of the products are investigated by Lambda 900-UV/Vis/IR Perkin Elmer spectrophotometer up to $1200 \mathrm{~nm}$.

\section{Study Snails Source And Maintenance}

Adult $B$. alexandrina, snails ( $8-10 \mathrm{~mm}$ in diameter; $0.26 \mathrm{~g}$ weight) have been obtained from Theodor Bilharz Research Institute (TBRI), (Giza, Egypt). Snails were transferred to Medical Malacology Lab and kept in plastic tank with dechlorinated aerated tap water (10 snails/ L) with a photoperiodicity of $12 \mathrm{hr}$. light/12 hr. dark cycle, a temperature of $25 \pm 3^{\circ} \mathrm{C}$ and fed on oven dried lettuce leaves ( $1 \mathrm{gm} / 10$ snails) and Tetramin. The tank water was changed every three days. For collecting egg masses, pieces of polyethylene sheets $(5 \times 10 \mathrm{~cm})$ were used $(O E C D, 2016)$.

\section{Toxicity Study}

\subsection{Acute toxicity test in adult $B$. alexandrina}

The toxicity of the two layered material Co-Fe-Cd and Co-Fe-Cd/Pbl 2 LDH against adult mature snails (10-12 mm) were determined. Stock solution of two layered material was prepared using dechlorinated tap water $(1000 \mathrm{mg} / \mathrm{L})$. A series of concentrations was prepared to calculate $\mathrm{LC}_{50}$ and $\mathrm{LC}_{90}$ at laboratory temperature $\left(22-25^{\circ} \mathrm{C}\right)$. Three replicates were conducted for each concentration and the control group (30 snails per experimental group). 72 hour after, the snails were transferred from the exposure concentrations, and maintained in dechlorinated tap water for another 24 hours of recovery. Mortality percent of snails were recorded and lethal concentration and slope values were analyzed by Probit analysis (WHO 1965).

\subsection{Embryo-toxicity test.}

According to Rapado et al., (2011) pieces of polyethylene sheets $(5 \times 10 \mathrm{~cm})$ containing egg clutches (100 eggs) were collected for the embryotoxicity assay. The egg masses were transferred to Petri dishes contains $\mathrm{LC}_{25}$ of $\mathrm{LDH}$ for $24 \mathrm{~h}$, subsequently washed with filtered and dechlorinated water (pH 7.0). Seven days after exposure, the embryos were examined for unviability (malformed embryos or dead) by 
stereomicroscope. Another egg clutches was transferred to dechlorinated aerated tap water as a control. Assays were performed in triplicate.

\subsection{Scanning Electron Microscope of the mantle-foot region}

The mantle foot regions of snails were separated under a stereomicroscope. Then, the specimens were fixed, dehydrated, critically dried and coated as recommended by Ibrahim and Abdel-Tawab (2020). Finally, they were photographed by JSM-6510 LA.

\subsection{Immunocytotoxicity:}

\subsubsection{Cytotoxicity assay in hemocytes of B. alexandrina}

According to Nduku and Harrison, 1980, the hemolymph was collected from the snail heart by insertion a capillary tube into the snail shell that is directly over the heart. $10 \mu$ of hemolymph was spared on a glass slide to prepared hemocytes monolayers and leave to air- dry for $15 \mathrm{~min}$ at laboratory temperature. Hemocytes were fixed with 100\% methanol for 5 min and then stained with 10\% Giemsa stain (Aldrich) for $20 \mathrm{~min}$, then examined under the light microscope. This assay was done in triplicate for each group. Morphological changes observed were classified.

\subsubsection{Measurement of IL-2 level and Caspase-3 activity}

IL-2 in tissue homogenate was measured by enzyme linked immunosorbant assay (ELISA). Cytokine levels were determined by commercially available ELISA kits for IL-2 (OptEIA ${ }^{\mathrm{TM}}$ Kits; BD Biosciences). The depth of the color can then be measured spectrophotometrically at appropriate wave length. The intensity of colored end product provided a measure of the cytokine concentration (Hemdan et al. 2007). Caspase3 activity was determined according to Bonomini et al., 2004. The released p-nitroaniline (pNA) moiety concentration was measured colorimetrically at $405 \mathrm{~nm}$.

\subsection{Tissue preparation for oxidant/antioxidant biomarker and biochemical studies}

The snail soft tissues were removed from the exposure group and the control one, weighted, and then homogenized in ice cold, twice-distilled water using a glass Dounce homogenizer. The supernatants were separated using high speed centrifuged (3000 rpm for $10 \mathrm{~min}$ ) and stored at $-80{ }^{\circ} \mathrm{C}$ until used.

\subsubsection{Oxidant/antioxidant defense biomarker:}

These biomarkers have been measured in the supernatant of the tissue homogenate for LDH exposure group and control one. The enzymatic responses SOD, CAT and GST were measured according to Aebi 1984, (Mannervik and Guthenberg 1981). While, non-enzymatic responses GSH, was determined according to the method of Ellman, 1959. For biochemical Studies the snails' total protein was done according to the method of Gornall et al., 1949. All parameter determined using biodiagnostic kits (Biodiagnostic Dokki, Giza, Egypt). 


\subsection{Genotoxicity:}

4.6.1 Detecting of DNA single strand breaks (Comet assay)

DNA single strand damage of snails exposed to $\mathrm{LC}_{25}$ of $\mathrm{LDH}$ for $48 \mathrm{~h}$ was detected by single cell gel assay as previously described by Singh et al., 1988 and Grazeffe et al., 2008.

\subsection{Histological evolution of the gland}

After two weeks of exposure and recovery, adult $B$. alexandrina snails $(8-10 \mathrm{~mm})$ were selected randomly and dissected. The digestive and hermaphrodite gland were removed, and fixed in Bouin's solution. The glands dehydrated, embedded in paraffin wax. then, the both sectioned and stained with hematoxylin and eosin (Mohamed and Saad 1990). The digestive and hermaphrodite gland were examined by light microscopy for any alteration in compared to control snails

\section{Statistical Analysis}

Data analysis were performed by t-test to determine the significant difference between exposure and control group and expressed as mean \pm SME of mean (Graph Pad Prism 6.04 software). The lethal concentration ( $\mathrm{LC}_{10}, \mathrm{LC}_{25}, \mathrm{LC}_{50}$, and $\mathrm{LC}_{90}$ ) values, slope and respective $95 \%$ Confidence limit $(\mathrm{CL})$ of $\mathrm{LC} \mathrm{C}_{50}$ was calculated by Probit analysis (Finney 1971).

\section{Result}

\subsection{Characterization of Co-Cd-Fe LDH, and T-LDH/Pbl 2 NC}

\subsubsection{Function groups identification}

The FTIR charts of (Co-Cd-Fe) LDH and its composite are displayed in Fig. 1A (A, B), and Table 1. After combination of $\mathrm{Pbl}_{2}$, there are red shifts in absorption bands and some peaks changed in intensity and other broads Fig. 1A (B).

\subsubsection{Structural properties}

The structure and crystalinity of (Co-Cd-Fe) LDH was confirmed by XRD diffract gram. Its chart displays highly matching of hydrotalcite LDH with hexagonal phase (Fig. 1B). XRD peaks referred to diffractions (003), (006), (101), (009), (107), (018), (110), and (113). It is noticed that these peaks have high intensity which was reflected the high crystallinity of the studied LDH.

Their crystal sizes were calculated using Scherrer's relation [R]. The mean size was $23.5 \mathrm{~nm}$. In addition to their average microstrain value was $\sim 0.7 \%$ and its dislocations density was 0.0018 that evaluates the density of defects and the quality of the crystal. This result gives a reflection to high quality of the synthesized LDH crystal. 


\subsubsection{Morphological properties}

The morphological properties were examined through FESEM and TEM, at fig. 1C (A, B). The morphology of Co-Cd-Fe LDH was characterized with the agglomeration of the particles which have plate like morphology $[r]$. This behavior was similar for all hydrotalcite prepared by co-precipitation method. TEM clarified the plate like of LDH layers and proved the morphology of the LDH.

\subsection{Toxic impact of LDH on adult B. alexandrina}

In the present study Co-Cd-Fe LDHs and Co-Cd-Fe LDHs / $/ \mathrm{Pbl}_{2}(\mathrm{LDH})$ was tested for its toxic effect against B. alexandrina. Snails were exposed to different concentrations of Co-Cd-Fe LDHs and Co-Cd-Fe LDHs $/ \mathrm{Pbl}_{2}(\mathrm{LDH})$ for $72 \mathrm{~h}$ of exposure followed by another $24 \mathrm{~h}$ for recovery. Probit analysis showed that the $\mathrm{LC}_{50}$ and $\mathrm{LC}_{90}$ of Co-Cd-Fe LDHs were 147.7 and 205.9, respectively. While Co-Cd-Fe / $\mathrm{Pb}_{2} \mathrm{LDH}$ showed more toxic effect, $\mathrm{LC}_{50}$ and $\mathrm{LC}_{90}$ were 56.4 and $95.3 \mathrm{mg} / \mathrm{l}$ (Table 2).

\subsection{Embryo-toxicity}

The results of the LDH embryotoxicity are illustrated in fig. 2. Exposure to Co-Cd-Fe LDHs caused suppression of embryonic development, embryo malformation and accumulation of LDH NPs in the eggclutches (fig. 2B).

\subsection{Effect of LDH on B. alexandrina ultrasturacture:}

The scanning electron micrographs of the soft part of Biomphalaria alexandrina snails showing the normal foot plantaris with notable surface fold and covered with fine and smooth cilia (Fig. 3A), and tegmental surface of mantle with microvilli and fine spines (Fig. 3D). Following the exposure to $\mathrm{LC}_{25}$, the foot cilia became tangled, adherent, and ultimately peeled off (fig. 3A and 3B). Also, the tegmental surface of mantle became rough, most microvilli completely destroyed, nipples and erosion (Fig. $3 \mathrm{E}$ and $3 F)$.

\subsection{Impact of LDH on hemocytes of B. alexandrina}

In control group, microscopical examinations of $B$. alexandrina hemocytes showed three types of cell that differentiated morphologically. The first type is hyalinocytes; the second is granulocytes (spreading hemocytes), and the third is round small (undifferentiated) (Fig. 4A, 4B, 4C). After exposure to the LDH at sub lethal concentration $\left(\mathrm{LC}_{25}\right)$, hyalinocytes nucleus showed shrinkage and others had two separate nuclei; also, aggregations of hyalinocytes were more evident after exposure to $\mathrm{LC}_{25}$. While, granulocytes having irregular cell membrane, aggregate and formed either pseudopodia or filopodia (Fig. 4D, 4E).

\subsection{Influence of LDH on IL-2 level and caspase-3 activity}

In the present study, there are a marked increase in expression of IL-2 in LDH exposure group $(p<0.001)$ in compared to non-exposure one (fig. 5B). While, caspase-3 activity was slightly increased $(p<0.05)$ (fig. 
$5 A)$.

\subsection{Impact of LDH on oxidant/antioxidant defense biomarker and biochemical studies:}

In the present study, Exposing of snails to $\mathrm{LC}_{25}$ of LDH induced significant decreased $(p<0.001)$ in SOD and CAT ( $p<0.01$ ) activity compared to the non- exposer group (control), (fig. $6 \mathrm{~A}$ and $6 \mathrm{~B}$ ) with no change in GST activity (Pख0.05), (fig. 6C). Concomitantly, a significant decrease of GSH levels and total protein content $(p<0.001)$ in tissue homogenate was observed in LDH exposure group compared with their timematched controls (fig. 6D and 6E).

\subsection{Influence of LDH on DNA}

The present results showed that the olive tail moment (OTM) of snails subjected to sub lethal concentrations of LDH was highly increased $(p<0.01)$ than control snails (fig. 7A and 7B)

\subsection{Impact of LDH on digestive and hermaphrodite gland of $B$. alexandrina}

Examination of the histological sections through digestive gland showed many tubular glands with single layer of secretory cells (SC) and digestive cells (DC) (Fig. 8A). Treatment these snails with $\mathrm{LC}_{25}$ of LDH, showed rupturing, vacuolation and a significant increase in the number of $\mathrm{SC}$. also, the lumen $(\mathrm{L})$ increased, most of the DC and SC were degenerated and ruptured while the tubular glands lose their confirmed shape (Fig. 8B). Meanwhile, the histological sections of $B$. alexandrina snails of the control group through the hermaphrodite gland revealed female oogenic cells with normal oocytes and mature ova and male reproductive cells with normal spermatocytes, and sperms (Fig. 8C). The treatment of snails with a dose of $\mathrm{LC}_{25}$ caused degenerations and destruction of some oocytes, mature ova, spermatocytes and sperms (Fig. 8D).

\section{Discussion}

Layered Double Hydroxide (LDH) gains significant attention in life science applications due to their extremely governable synthesis and high biocompatibility. But, few studies highlight toxicity and toxicokinetic of LDH. In the present study, we engineered Co-Cd-Fe LDH, and T-LDH/Pbl 2 NC and its toxicological impact was evaluated. The results of Co-Cd-Fe LDH characterization by XRD were matched with a usual LDH with crystallinity mean size $23.5 \mathrm{~nm}$ (Lu et al., 2015; Mohamed et al. 2018). Also, their FTIR spectra were similar to that previously recorded (Shaban et al. 2018; Mohamed et al. 2018; Parida and Mohapatra 2012). While, FSEM and TEM clarified the plate like of LDH layers (Tedim et al. 2011; Chen et al. 2017).

It was proven that LDH has toxic impact against human cell line (Choi et al., 2007) and green algae Scenedesmus quadricauda (Ding et al., 2018). In the present study, Co-Cd-Fe LDH, and T-LDH/Pbl 2 NC showed toxic effect against $B$. alexandrina and T-LDH/Pbl 2 NC more toxic to adult Biomphalaria than CoCd-Fe LDHs with $\mathrm{LC}_{50}$ of $56.4 \mathrm{mg} / \mathrm{L}$. 
Enzymatic (GST, SOD and CAT) and non-enzymatic (GSH) antioxidant markers play a vital role in protection the organisms from oxidative stress and suppression of its cellular damage as it reduce and converted $\mathrm{H}_{2} \mathrm{O}_{2}$ and superoxide anion radical. While, GSH act as a reducing agent in conjugation with xenobiotics (Pena-Llopis et al. 2001). Disturbance of oxidant/antioxidant system has been the main toxic impact induced by NMs in snails. LDH increased the ROS production and subsequently altered the enzymatic and non- enzymatic antioxidant enzyme, such as SOD,CAT, GSH (Ali, 2014b; Ali et al., 2012; Bao et al., 2018). In addition, this reduction can be elucidated to the direct combination of metal with active site of enzyme and its bio-transformation. The present data showed significant decrease in SOD, CAT, GSH and this in agreement with Gnatyshyna et al., 2020 as non-enzymatic marker activity decreased in Lymnaea stagnalis after exposure to $\mathrm{Cu}, \mathrm{Zn}, \mathrm{Cd}$ and Thiocarbamate. Also, a decrease of catalase activity was seen previously in snail exposed to herbicides (Bhagat et al. 2016). In addition, exposure of B. alexanderina snails to ZnONPs showed significant inhibition of GSH and CAT ((Fahmy et al. 2014). In contrast with our result, Atli and Grosell, 2016 reported that exposing L. stagnalis to only the highest concentrations of $\mathrm{Cu}$ caused an increase in antioxidant enzyme.

Exposed snails showed no significant variation in GST activity compared to control. This finding agreed with those obtained by Sánchez-Marín et al., 2020 as they indicated that this enzyme is not activated in response to Organophosphate flame retardants, tris (1,3-dichloro-2-propyl) phosphate in mussels

Also, the present study declared a marked decrease in the total protein content $(p<0.001)$ compared with controls. Fahmy et al., 2014, recorded a significant decrease in B. alexanderina snail protein content after exposure to ZnONPs. Whatever, activity of antioxidant marker differed depending upon the tissue type and metal concentrations and animal species. SOD and CAT activity in Daphnia magna exposed to Cd and $\mathrm{Cu}$ varied according to metal concentration. Also, L. natalensis snails collected from polluted dams in Zimbabwe showed variation in SOD and CAT activity (Siwela et al., 2010) . In addition, Achatina fulica showed reduction in CAT and SOD activities after exposure to $\mathrm{Cd}$ and $\mathrm{Zn}$. This variation could be attributed to the excess production of ROS (Chandran et al., 2005). Similarly such enzyme reductions were also observed in the present study in response to LDH exposure.

A slightly increase of caspase-3 activity was detected as unspecific response to LDH stress. Its elevation was observed previously in apoptotic cells (Elmore, 2007; Florentin and Arama, 2012), and this elevation may be due to cytological changes in the digestive gland of LDH-stressed snails (Zaldibar et al., 2007a, 2007b; Hödl et al. 2010; Benito et al., 2017). Previously, increasing in caspase-3 activity has been detected in L. stagnalis in response to pollutant stress ((Gnatyshyna et al. 2020). Also, caspases-3 levels increased in Helix aspersa snails after exposure to iron oxides nanoparticles (Sidiropoulou et al. 2018)

In the declared data, $\mathrm{LDH}$ at sub lethal concentration $\left(\mathrm{LC}_{25}\right)$, caused abnormalities in hyalinocytes and granulocytes shapes as nucleus shrinkage, divided to two separate nuclei, aggregate or formed pseudopodia. The immuno-cell responses and molecular aspects in $B$. alexandrina snails considered as important biomarkers of exposure to environmental pollutants (Mohamed 2011). Biomphalaria snails immunology can be attributed to hemocyte which are the critical line of cellular defense (Larson et al. 
2014), where, they contributed in many defense mechanism against several pathogen as it is responsible for the phagocytosis, cytotoxic reactions (Fried 2016) and release soluble compounds including agglutinins and antimicrobial peptides (Ottaviani, 2006; Mitta et al., 2000).

Chronic exposure of the T. pisana to Ag NPs caused alterations in hemocytes, such as micronuclei, binucleated cell and kidney-like nuclei (Radwan et al. 2019). Also, B. glabrata exposed to CdTe quantum dot showed altered hemocytes binucleates, micronuclei, and apoptosis (de Vasconcelos Lima et al. 2019). Cell-cell aggregation was considered as an immunological response for host defense. Cellular aggregation of the invertebrates' hemocytes prevented the accidental blood loss by the formation of a biological plug at the site of the wound and resisted the entry of pathogenic microorganism (Guria et al. 2016).

Hughes et al., 1990 and Ottaviani et al., 1993 were detected cytokine-like molecules in marine and freshwater mollusks. IL-2 was one of the cytokines assayed. It is responsible for phagocytosis and provokes the strongest response in the synthesis of biogenic amines, nitric oxide (NO) or oxygen radicals (Ottaviani et al. 1995a, b). In the present study, there are a marked increase in expression of IL-2 in LDH exposure group $(p<0.001)$ in compared to non-exposure one. (IL)-2-like peptide were also detected in sea mussel which may be involved in the regulation of responses to different types of stress (Cao, 1998; Barcia et al., 1999).

On the level of DNA damage, as an important biomarker of NM toxicity in snails. Comet assay is a sensitive tool to detect DNA damages like DNA single-strand breaks (SSBs) (Ibrahim et al. 2018). The present results showed that the olive tail moment (OTM) of snails exposed to sub lethal concentrations was increased than control snails. This in agreement with (Ibrahim and Ghoname 2018) who demonstrated that the OTM of snails exposed to $\mathrm{LC}_{10}\left(27.5 \mathrm{mg} \mathrm{L}^{-1}\right)$ or $\mathrm{LC}_{25}\left(32.4 \mathrm{mg} \mathrm{L}^{-1}\right)$ of the aqueous leaves extract of Anagalis arvensis was significantly higher than the control group. Such genotoxic effects might be due to either oxidation of DNA bases or covalent binding to DNA resulting in strand breaks. Some recent studies link DNA SSBs in aquatic animals to effects on the immune system, reproduction, growth, and population dynamics (Lee and Steinert, 2003). Exposure to inorganic nanomaterial as Ag NPs, CuO NPs, IONPs, MgO NPs, TiO2 NPs, and ZnO NPs induced genotoxic effects in snails (Caixeta et al. 2020).

The embryotoxicity observed after exposure has been attributed to ROS production, oxidative stress and damage. Also, penetration of LDH NPs to gelatinous capsule and cross the egg membrane reduce essential growth metabolism aspects, changes in its permeability, consuming energy for the development and finally interrupting the mechanics of hatching (de Chavez and de Lara, 2003; de Vasconcelos Lima et al., 2019).

Our result in agreement with Besnaci et al., 2016, who state morphological changes and precipitation of $\mathrm{Fe}_{2} \mathrm{O}_{3} \mathrm{NPs}$ in the egg mass. Also, morphological abnormality and hatchability hinder was seen in $B$. pfeifferi embryos following exposure to curcumin-nisin polylactic acid NPs for $96 \mathrm{~h}$. In addition, 
Hydrophilic nanosilica induced embryotoxic effects in $B$. alexandrina snail at concentration $590 \mathrm{ppm}$ for $6 \mathrm{~h}$ and $980 \mathrm{ppm}$ for $48 \mathrm{~h}$ ((Attia et al. 2017). Similarly, the growth and hatching rate reduction was seen in B. glabrata embryos exposed to CdTe NPs for $24 \mathrm{~h}$ (Vasconcelos - Lima et al., 2019). In contrast, dimer captosuccinic acid (DMSA)-functionalized $\mathrm{Fe}_{2} \mathrm{O}_{3} \mathrm{NPs}$ did not induce embryo mortality, morphological alterations and hatching inhibition due to their physical properties and limited internalization in the eggclutches (Oliveira-filho et al., 2016). LDH posed a significant suppression in the growth of S. quadricauda algae after $72 \mathrm{~h}$ of incubation and a complete growth inhibition (100\%) at higher LDH concentration. LDH had a higher inhibitory effect to growth than the other NPs (Ding et al., 2018).

In the present study, the foot and mantle of Biomphalaria alexandrina snails showed bioaccumulation of $\mathrm{LDH}$ in its surface and some morphological disturbances after the exposure to $\mathrm{LDH}$ for $24 \mathrm{~h}$ followed by $24 \mathrm{~h}$ recovery as was detected by scanning electron microscope. LDH can interact, accumulated in foot and digestive gland of snails, and distributed to the mantle. Both Ag NPs and CuO NPs accumulation in mantle, foot and digestive gland of $B$. aeruginosa (Bao et al., 2018; Oliver et al., 2014; Croteau et al., 2014; Ma et al., 2017). Also, NMs possessed a highly adhesive property to a cell membrane therefore, it could affect the membrane structures and its macromolecules (Rasel et al. 2019). In addition this damage in ultrastructure could lead to snail death (Ibrahim and Abdel-Tawab 2020).

The deformation declared in the hermaphrodite gland of $B$. alexandrina histological sections after exposure to $\mathrm{LC}_{25}$ of $\mathrm{LDH}$ was accompanied with a great damage in the gonadal cells where degenerations of some mature ova, spermatocytes, oocytes and sperms. Also, the connective tissue was dissolved and replaced by vacuoles. Saad et al. (2019) reported similar histological alterations in the hermaphrodite glands of $B$. alexandrina snails treated with copper oxide nano- composite (CuO NC), where, the ova and sperms degenerated and there were loss in the connective tissues between acini (Saad et al. 2019). The exposure of the snail to LDH may be lead to metabolic changes, destruction of gametogenic cells and damage of hermaphrodite glands which possibly resulting from a decrease in tissue proteins, apoptosis, or degeneration of cells of these vital organs (Omobhude et al. 2017).

The digestive gland was the main organ analysed in studies concerning oxidative stress induced by NM due to its higher accumulation capacity and role in the metal detoxification. Exposing of the digestive gland of $B$. alexandrina snails to $\mathrm{LC}_{25}$ of the $\mathrm{LDH}$, showed significant increase in the number and degeneration of the SC. The DC ruptured and vacuolated in addition, the tubular glands lose their confirmed shape. In like manner, Saad et al. reported histological alterations in the digestive gland of Coelatura aegyptiaca following treatment with ZnONPs for 6 consecutive days, where, there were gradual hypertrophy and hyperplasia in the glandular cells (Fahmy and Sayed 2017).

\section{Conclusion}

The data of the current study consider, the first toxicological evaluation of LDH nanomaterial on freshwater snail $B$. alexandrina. In light of the above, LDH induce disturbance in both enzymatic and nonenzymatic antioxidant marker in the tissues of Biomphalaria following exposure to sublethal

Page $11 / 26$ 
concentration, suppression the embryonic development. It caused alteration in mantle foot ultrastructure, immune response, histopathology of gland, and finally, genotoxic effect. This result reflects the possible ecological implications of LDH release in aquatic ecosystems and its risk assessment to aquatic invertebrate.

\section{Declarations}

Funding: Not applicable

Conflicts of interest/Competing interests: The authors declare that they have no known competing financial interests or personal relationships that could have appeared to influence the work reported in this paper.

Availability of data and material: The data that supports the findings of this study are available in the material of this article

Code availability: Not applicable

\section{Authors' contributions:}

Conceived and designed experiments; Heba Abdel-Tawab, Amina M. Ibrahim

Data curation; Taghreed Hussein; Fatma Mohamed

Formal analysis; Taghreed Hussein; Fatma Mohamed

Methodology; Heba Abdel-Tawab, Amina M. Ibrahim

Software; Taghreed Hussein; Fatma Mohamed

Supervision; Heba Abdel-Tawab, Amina M. Ibrahim

Validation; Heba Abdel-Tawab, Amina M. Ibrahim

Visualization; Heba Abdel-Tawab, Amina M. Ibrahim

Roles/Writing-original draft; Taghreed Hussein; Fatma Mohamed

Writing - review \& editing; Heba Abdel-Tawab, Amina M. Ibrahim

Ethics approval: Not applicable

Consent to participate: Not applicable

Consent for publication: Not applicable 


\section{References}

Aebi, H., 1984. Catalase in vitro. Method Enzymol 105:121-126 Allain CC, Poon LS, Chan CS, Richmond W, Fu PC (1974) Enzymatic determination of total serum cholesterol. J Clin Chem 20:470-475

Ali D (2014) Oxidative stress-mediated apoptosis and genotoxicity induced by silver nanoparticles in freshwater snail Lymnea luteola L. Biological trace element research 162:333-341

Ali D, Alarifi S, Kumar S, et al (2012) Oxidative stress and genotoxic effect of zinc oxide nanoparticles in freshwater snail Lymnaea luteola L. Aquatic toxicology 124:83-90

Amorim J, Abreu I, Rodrigues P, et al (2019) Lymnaea stagnalis as a freshwater model invertebrate for ecotoxicological studies. Science of The Total Environment 669:11-28

Atli G, Grosell M (2016) Characterization and response of antioxidant systems in the tissues of the freshwater pond snail (Lymnaea stagnalis) during acute copper exposure. Aquatic Toxicology 176:38-44

Attia MM, Soliman SM, Khalf MA (2017) Hydrophilic nanosilica as a new larvicidal and molluscicidal agent for controlling of major infectious diseases in Egypt. Veterinary World 10:1046-1051. https://doi.org/10.14202/vetworld.2017.1046-1051

Bao S, Huang J, Liu X, et al (2018) Tissue distribution of Ag and oxidative stress responses in the freshwater snail Bellamya aeruginosa exposed to sediment-associated Ag nanoparticles. Science of the total environment 644:736-746

Barcia R, Cao A, Arbeteta J, Ramos-Martinez JI (1999) The IL-2 receptor in hemocytes of the sea mussel Mytilus galloprovincialis Lmk. IUBMB life 48:419-423

Bazrafshan AA, Ghaedi M, Hajati S, et al (2017) Synthesis of ZnO-nanorod-based materials for antibacterial, antifungal activities, DNA cleavage and efficient ultrasound-assisted dyes adsorption. Ecotoxicology and environmental safety 142:330-337

Benício LPF, Pinto FG, Tronto J (2020) Layered double hydroxide nanocomposites for agricultural applications. In: Layered Double Hydroxide Polymer Nanocomposites. Elsevier, pp 715-741

Benito D, Niederwanger M, Izagirre U, et al (2017) Successive onset of molecular, cellular and tissuespecific responses in midgut gland of Littorina littorea exposed to sub-lethal cadmium concentrations. International Journal of Molecular Sciences 18:1815

Besnaci S, Bensoltane S, Braia FMH, et al (2016) Embryotoxicity evaluation of iron oxide Fe2O3 on land snails: Helix aspersa. Journal of Entomology and Zoology Studies 4:317-323

Bhagat J, Ingole BS, Singh N (2016) Glutathione S-transferase, catalase, superoxide dismutase, glutathione peroxidase, and lipid peroxidation as biomarkers of oxidative stress in snails: A review. 
Invertebrate Survival Journal 13:336-349

Bonomini M, Dottori S, Amoroso L, et al (2004) Increased platelet phosphatidylserine exposure and caspase activation in chronic uremia. Journal of Thrombosis and Haemostasis 2:1275-1281

Caixeta MB, Araújo PS, Gonçalves BB, et al (2020) Toxicity of engineered nanomaterials to aquatic and land snails: A scientometric and systematic review. Chemosphere 127654

Cao A (1998) El receptor de IL-2 en hemocitos deMytilus galloprovinciali s Lmk

Chandran R, Sivakumar AA, Mohandass S, Aruchami M (2005) Effect of cadmium and zinc on antioxidant enzyme activity in the gastropod, Achatina fulica. Comparative Biochemistry and Physiology Part C: Toxicology \& Pharmacology 140:422-426

Chen C, Yu W, Liu T, et al (2017) Graphene oxide/WS2/Mg-doped ZnO nanocomposites for solar-light catalytic and anti-bacterial applications. Solar Energy Materials and Solar Cells 160:43-53

Choi S-J, Choy J-H (2011) Layered double hydroxide nanoparticles as target-specific delivery carriers: uptake mechanism and toxicity. Nanomedicine 6:803-814

Corsi I, Winther-Nielsen M, Sethi R, et al (2018) Ecofriendly nanotechnologies and nanomaterials for environmental applications: key issue and consensus recommendations for sustainable and ecosafe nanoremediation. Ecotoxicology and environmental safety 154:237-244

Croteau M-N, Misra SK, Luoma SN, Valsami-Jones E (2014) Bioaccumulation and toxicity of CuO nanoparticles by a freshwater invertebrate after waterborne and dietborne exposures. Environmental science \& technology 48:10929-10937

Daniel S, Thomas S (2020) Layered double hydroxides: fundamentals to applications. In: Layered Double Hydroxide Polymer Nanocomposites. Elsevier, pp 1-76

de Chavez ERC, de Lara A V (2003) Effects of zinc (Zn2+) and lead (Pb2+) on the early development of the freshwater snail, Radix quadrasi. J Med Appl Malacol 12:59-68

de Vasconcelos Lima M, de Andrade Pereira MI, Cabral Filho PE, et al (2019) Studies on Toxicity of Suspensions of CdTe Quantum Dots to Biomphalaria glabrata Mollusks. Environmental toxicology and chemistry 38:2128-2136

DeJong RJ, Morgan JAT, Paraense WL, et al (2001) Evolutionary relationships and biogeography of Biomphalaria (Gastropoda: Planorbidae) with implications regarding its role as host of the human bloodfluke, Schistosoma mansoni. Molecular biology and evolution 18:2225-2239

Ding T, Lin K, Chen J, et al (2018) Causes and mechanisms on the toxicity of layered double hydroxide $(\mathrm{LDH})$ to green algae Scenedesmus quadricauda. Science of The Total Environment 635:1004-1011 
Duft M, Schmitt C, Bachmann J, et al (2007) Prosobranch snails as test organisms for the assessment of endocrine active chemicals--an overview and a guideline proposal for a reproduction test with the freshwater mudsnail Potamopyrgus antipodarum. Ecotoxicology 16:169-182

Ellman GL (1959) Tissue sulfhydryl groups. Archives of biochemistry and biophysics 82:70-77

Elmore S (2007) Apoptosis: a review of programmed cell death. Toxicologic pathology 35:495-516

Fahmy SR, Abdel-Ghaffar F, Bakry FA, Sayed DA (2014) Ecotoxicological effect of sublethal exposure to zinc oxide nanoparticles on freshwater snail Biomphalaria alexandrina. Archives of environmental contamination and toxicology 67:192-202

Fahmy SR, Sayed DA (2017) Toxicological perturbations of zinc oxide nanoparticles in the Coelatura aegyptiaca mussel. Toxicology and Industrial Health 33:564-575.

https://doi.org/10.1177/0748233716687927

Finney DJ (1971) Probit Analysis, Cambridge University Press. London

Florentin A, Arama E (2012) Caspase levels and execution efficiencies determine the apoptotic potential of the cell. Journal of Cell Biology 196:513-527

Fried B (2016) An update on hemocytes in Biomphalaria snails. Journal of Hematology and Oncology Research 2:20

Gnatyshyna L, Falfushynska H, Stoliar O, Dallinger R (2020) Preliminary Study of Multiple Stress Response Reactions in the Pond Snail Lymnaea stagnalis Exposed to Trace Metals and a Thiocarbamate Fungicide at Environmentally Relevant Concentrations. Archives of Environmental Contamination and Toxicology

Gornall AG, Bardawill CJ, David MM (1949) Determination of serum proteins by means of the biuret reaction. Journal of biological chemistry 177:751-766

Grazeffe VS, de Freitas Tallarico L, de Sa Pinheiro A, et al (2008) Establishment of the comet assay in the freshwater snail Biomphalaria glabrata (Say, 1818). Mutation Research/Genetic Toxicology and Environmental Mutagenesis 654:58-63

Guria S, Parveen S, Goswami DS (2016) Alteration of morphology, phagocytic behaviour and aggregation of insect haemocytes exposed to contaminated food with arsenic and lead. International Journal of PharmTech Research 9:177-186

Han J, Xu X, Rao X, et al (2011) Layer-by-layer assembly of layered double hydroxide/cobalt phthalocyanine ultrathin film and its application for sensors. Journal of Materials Chemistry 21:21262130 
Hemdan NYA, Lehmann I, Wichmann G, et al (2007) Immunomodulation by mercuric chloride in vitro: application of different cell activation pathways. Clinical \& Experimental Immunology 148:325-337

Hughes TK, Smith EM, Chin R, et al (1990) Interaction of immunoactive monokines (interleukin 1 and tumor necrosis factor) in the bivalve mollusc Mytilus edulis. Proceedings of the National Academy of Sciences 87:4426-4429

Ibrahim AM, Abdel-Tawab H (2020) Cystoseira barbata marine algae have a molluscicidal activity against Biomphalaria alexandrina snails supported by scanning electron microscopy, hematological and histopathological alterations, and larvicidal activity against the infective stages of Schis. Biologia 1-10

Ibrahim AM, Ghoname SI (2018) Molluscicidal impacts of Anagallis arvensis aqueous extract on biological, hormonal, histological and molecular aspects of Biomphalaria alexandrina snails. Experimental Parasitology 192:36-41. https://doi.org/10.1016/j.exppara.2018.07.014

Ibrahim, M. A, Ahmed, et al (2018) Hematological, physiological and genotoxicological effects of Match $5 \%$ EC insecticide on Biomphalaria alexandrina snails. Ecotoxicology and Environmental Safety 147:. https://doi.org/10.1016/j.ecoenv.2017.09.059

Kaloyianni M, Dimitriadi A, Ovezik M, et al (2020) Magnetite nanoparticles effects on adverse responses of aquatic and terrestrial animal models. Journal of hazardous materials 383:121204

Khangarot BS, Das S (2010) Effects of copper on the egg development and hatching of a freshwater pulmonate snail Lymnaea luteola L. Journal of Hazardous Materials 179:665-675

Kim K-T, Jang M-H, Kim J-Y, et al (2012) Embryonic toxicity changes of organic nanomaterials in the presence of natural organic matter. Science of the total environment 426:423-429

Ladewig K, Xu ZP, Lu GQ (2009) Layered double hydroxide nanoparticles in gene and drug delivery. Expert Opinion on Drug Delivery 6:907-922

Larson MK, Bender RC, Bayne CJ (2014) Resistance of Biomphalaria glabrata 13-16-R1 snails to Schistosoma mansoni PR1 is a function of haemocyte abundance and constitutive levels of specific transcripts in haemocytes. International journal for parasitology 44:343-353

Lee RF, Steinert S (2003) Use of the single cell gel electrophoresis/comet assay for detecting DNA damage in aquatic (marine and freshwater) animals. Mutation Research/Reviews in Mutation Research 544:43-64

Li R, Wang JJ, Zhou B, et al (2016) Enhancing phosphate adsorption by Mg/Al layered double hydroxide functionalized biochar with different Mg/Al ratios. Science of the Total Environment 559:121-129

Long Z, Ji J, Yang K, et al (2012) Systematic and quantitative investigation of the mechanism of carbon nanotubes' toxicity toward algae. Environmental science \& technology 46:8458-8466 
Ma T, Gong S, Tian B (2017) Effects of sediment-associated CuO nanoparticles on Cu bioaccumulation and oxidative stress responses in freshwater snail Bellamya aeruginosa. Science of the total environment 580:797-804

Mannervik B, Guthenberg C (1981) [28] Glutathione transferase (human placenta). In: Methods in enzymology. Elsevier, pp 231-235

Manzi-Nshuti C, Songtipya P, Manias E, et al (2009) Polymer nanocomposites using zinc aluminum and magnesium aluminum oleate layered double hydroxides: effects of LDH divalent metals on dispersion, thermal, mechanical and fire performance in various polymers. Polymer 50:3564-3574

Martins N, Pradhan A, Pascoal C, Cássio F (2020) Effects of metal nanoparticles on freshwater rotifers may persist across generations. Aquatic Toxicology 229:105652

Mitta G, Vandenbulcke F, Noël T, et al (2000) Differential distribution and defence involvement of antimicrobial peptides in mussel. Journal of Cell Science 113:2759-2769

Mohamed AH (2011) Sublethal toxicity of Roundup to immunological and molecular aspects of Biomphalaria alexandrina to Schistosoma mansoni infection. Ecotoxicology and environmental safety 74:754-760

Mohamed F, Abukhadra MR, Shaban M (2018) Removal of safranin dye from water using polypyrrole nanofiber/Zn-Fe layered double hydroxide nanocomposite (Ppy NF/Zn-Fe LDH) of enhanced adsorption and photocatalytic properties. Science of the Total Environment 640-641:352-363.

https://doi.org/10.1016/j.scitotenv.2018.05.316

Mohamed SH, Saad AA (1990) Histological studies on the hermaphrodite gland of Lymnaea caillaudi and Biomphalaria alexandrina upon infection with certain larval trematodes. Egypt. J Histol 13:47-53

Moustafa MA, Mossalem HS, Sarhan RM, et al (2018) The potential effects of silver and gold nanoparticles as molluscicides and cercaricides on Schistosoma mansoni. Parasitology research 117:3867-3880. https://doi.org/10.1007/s00436-018-6093-2

Myer MH, Henderson WM, Black MC (2017) Effects of multiwalled carbon nanotubes on the bioavailability and toxicity of diphenhydramine to Pimephales promelas in sediment exposures. Environmental toxicology and chemistry $36: 320-328$

Nduku WK, Harrison AD (1980) Cationic responses of organs and haemolymph of Biomphalaria pfeifferi (Krauss), Biomphalaria glabrata (Say) and Helisoma trivolvis (Say)(Gastropoda: Planorbirdae) to cationic alterations of the medium. Hydrobiologia 68:119-138

Oliveira-Filho EC, Nakano E, Tallarico L de F (2017) Bioassays with freshwater snails Biomphalaria sp.: from control of hosts in public health to alternative tools in ecotoxicology. Invertebrate Reproduction \& Development 61:49-57 
Oliver AL-S, Croteau M-N, Stoiber TL, et al (2014) Does water chemistry affect the dietary uptake and toxicity of silver nanoparticles by the freshwater snail Lymnaea stagnalis? Environmental pollution 189:87-91

Omobhude ME, Morenikeji OA, Oyeyemi OT (2017) Molluscicidal activities of curcumin-nisin polylactic acid nanoparticle on Biomphalaria pfeifferi. PLoS Neglected Tropical Diseases 11:e0005855. https://doi.org/10.1371/journal.pntd.0005855

Ottaviani E (2006) Molluscan immunorecognition. Invertebrate Survival Journal 3:50-63

Ottaviani E, Caselgrandi E, Franceschi C (1995a) Cytokines and evolution: in vitro effects of IL-1a, IL-1 $\beta$, TNF- $\alpha$ and TNF- $\beta$ on an ancestral type of stress response. Biochemical and biophysical research communications 207:288-292

Ottaviani E, Franchini A, Cassanelli S, Genedani S (1995b) Cytokines and invertebrate immune responses. Biology of the Cell 85:87-91

Ottaviani E, Franchini A, Franceschi C (1993) Presence of several cytokine-like molecules in molluscan hemocytes. Biochemical and biophysical research communications 195:984-988

Parida KM, Mohapatra L (2012) Carbonate intercalated Zn/Fe layered double hydroxide: a novel photocatalyst for the enhanced photo degradation of azo dyes. Chemical engineering journal 179:131139

Peligro FR, Pavlovic I, Rojas R, Barriga C (2016) Removal of heavy metals from simulated wastewater by in situ formation of layered double hydroxides. Chemical Engineering Journal 306:1035-1040

Pena-Llopis S, Pena JB, Sancho E, et al (2001) Glutathione-dependent resistance of the European eel Anguilla anguilla to the herbicide molinate. Chemosphere 45:671-681

Pirger Z, Zrinyi Z, Maász G, et al (2018) Pond snail reproduction as model in the environmental risk assesment: Reality and doubts. Biological Resources of Water Vol, S Ray, ed^ eds IntechOpen, London $33-53$

Radwan MA, El-Gendy KS, Gad AF, et al (2019) Responses of oxidative stress, genotoxicity and immunotoxicity as biomarkers in Theba pisana snails dietary exposed to silver nanoparticles. Chemistry and Ecology 35:613-630

Rapado LN, Nakano E, Ohlweiler FP, et al (2011) Molluscicidal and ovicidal activities of plant extracts of the Piperaceae on Biomphalaria glabrata (Say, 1818). Journal of helminthology 85:66

Rasel MAl, Singh S, Nguyen TD, et al (2019) Impact of Nanoparticle Uptake on the Biophysical Properties of Cell for Biomedical Engineering Applications. Scientific Reports 9:9: 5859.

https://doi.org/10.1038/s41598-019-42225-7

Page $18 / 26$ 
Ruppert K, Geiß C, Askem C, et al (2017) Development and validation of an OECD reproductive toxicity test guideline with the mudsnail Potamopyrgus antipodarum (Mollusca, Gastropoda). Chemosphere 181:589-599

Saad AEHA, Ragab FMA, Abdel Fatah HM, et al (2019) Effect of Cystoseira barbata and Dictyota dichotoma-algae on reproduction and protein pattern of Biomphalaria alexandrina snails. Molluscan Research 39:82-88. https://doi.org/10.1080/13235818.2018.1524740

Sánchez-Marín P, Vidal-Liñán L, Fernández-González LE, et al (2020) Proteomic analysis and biochemical alterations in marine mussel gills after exposure to the organophosphate flame retardant TDCPP. Aquatic Toxicology 105688

Shaban M, Mohamed F, Abdallah S (2018) Production and characterization of superhydrophobic and antibacterial coated fabrics utilizing ZnO nanocatalyst. Scientific reports 8:1-15

Sidiropoulou E, Feidantsis K, Kalogiannis S, et al (2018) Insights into the toxicity of iron oxides nanoparticles in land snails. Comparative Biochemistry and Physiology Part C: Toxicology \& Pharmacology 206:1-10

Singh NP, McCoy MT, Tice RR, Schneider EL (1988) A simple technique for quantitation of low levels of DNA damage in individual cells. Experimental cell research 175:184-191

Siwela AH, Nyathi CB, Naik YS (2010) A comparison of metal levels and antioxidant enzymes in freshwater snails, Lymnaea natalensis, exposed to sediment and water collected from Wright Dam and Lower Mguza Dam, Bulawayo, Zimbabwe. Ecotoxicology and Environmental Safety 73:1728-1732

Tarafdar JC, Sharma S, Raliya R (2013) Nanotechnology: Interdisciplinary science of applications. African Journal of Biotechnology 12:

Tedim J, Zheludkevich ML, Salak AN, et al (2011) Nanostructured LDH-container layer with active protection functionality. Journal of Materials Chemistry 21:15464-15470

WHO (1965) Molluscicide screening and evaluation. Bull WHO 33:567-581

Zaldibar B, Cancio I, Marigómez I (2007a) Reversible alterations in epithelial cell turnover in digestive gland of winkles (Littorina littorea) exposed to cadmium and their implications for biomarker measurements. Aquatic toxicology 81:183-196

Zaldibar B, Cancio I, Soto M, Marigómez I (2007b) Digestive cell turnover in digestive gland epithelium of slugs experimentally exposed to a mixture of cadmium and kerosene. Chemosphere 70:144-154

Zhao Y, Jiao Q, Li C, Liang J (2007) Catalytic synthesis of carbon nanostructures using layered double hydroxides as catalyst precursors. Carbon 45:2159-2163 
Zhu X, Zhu L, Chen Y, Tian S (2009) Acute toxicities of six manufactured nanomaterial suspensions to Daphnia magna. Journal of nanoparticle research 11:67-75

\section{Tables}

Table 1 FTIR peaks of Co-Cd-Fe LDH and its composite with $\mathrm{Pbl}_{2}$.

\begin{tabular}{|lll|}
\hline Function group & $\begin{array}{l}\text { Co-Cd-Fe } \\
\text { LDH }\end{array}$ & Composite \\
\hline H-stretching & 3424 & $\begin{array}{l}3390 \text { broaing of peak which is attributed to O-H stretching and } \\
\text { symmetric mode of Pb-l cluster }\end{array}$ \\
\hline the O-H bending & 1630 & $1629 \mathrm{~cm}-1$ \\
\hline $\begin{array}{l}\text { bending of H2O } \\
\text { molecule }\end{array}$ & 1350 & $1390 \mathrm{~cm}-1$ \\
\hline $\begin{array}{l}\text { NO3--stretching } \\
\text { mode26. }\end{array}$ & $1430 \mathrm{~cm}-1$ \\
\hline $\begin{array}{l}\text { M-O vibrations of } \\
\text { LDH. }\end{array}$ & $\begin{array}{l}\text { below1000 } \\
\text { cm-1 }\end{array}$ & 580 \\
\hline
\end{tabular}

Table 2: Shows molluscicidal activity of $\mathrm{Co}-\mathrm{Fe}-\mathrm{Cd}$ and $\mathrm{Co}-\mathrm{Cd}-\mathrm{Fe} / \mathrm{Pbl}{ }_{2}$ for adult $\mathrm{B}$. alexandrina, snails after $72 \mathrm{~h}$ of exposure followed by $24 \mathrm{~h}$ for recovery.

\begin{tabular}{|c|c|c|c|c|c|c|}
\hline & $\begin{array}{l}\mathrm{LC}_{10} \\
(\mathrm{mg} / \mathrm{L})\end{array}$ & $\begin{array}{l}\mathrm{LC}_{25} \\
(\mathrm{mg} / \mathrm{L}\end{array}$ & $\begin{array}{l}\mathrm{LC}_{50} \\
(\mathrm{mg} / \mathrm{L})\end{array}$ & Confidence limits of $\mathrm{LC}_{50}(\mathrm{mg} / \mathrm{L})$ & $\begin{array}{l}\mathrm{LC}_{90} \\
(\mathrm{mg} / \mathrm{L})\end{array}$ & Slope \\
\hline \multirow[t]{2}{*}{ Co-Cd-Fe } & & & & $110.99-188.07$ & 205.9 & 1.1 \\
\hline & 89.5 & 117.1 & 147.7 & & & \\
\hline \multirow[t]{2}{*}{ Co-Cd-Fe $/ \mathrm{Pbl}_{2}$} & & & & & & 1.2 \\
\hline & 17.4 & 35.91 & 56.4 & $21.52-85.07$ & 95.3 & \\
\hline
\end{tabular}

\section{Figures}



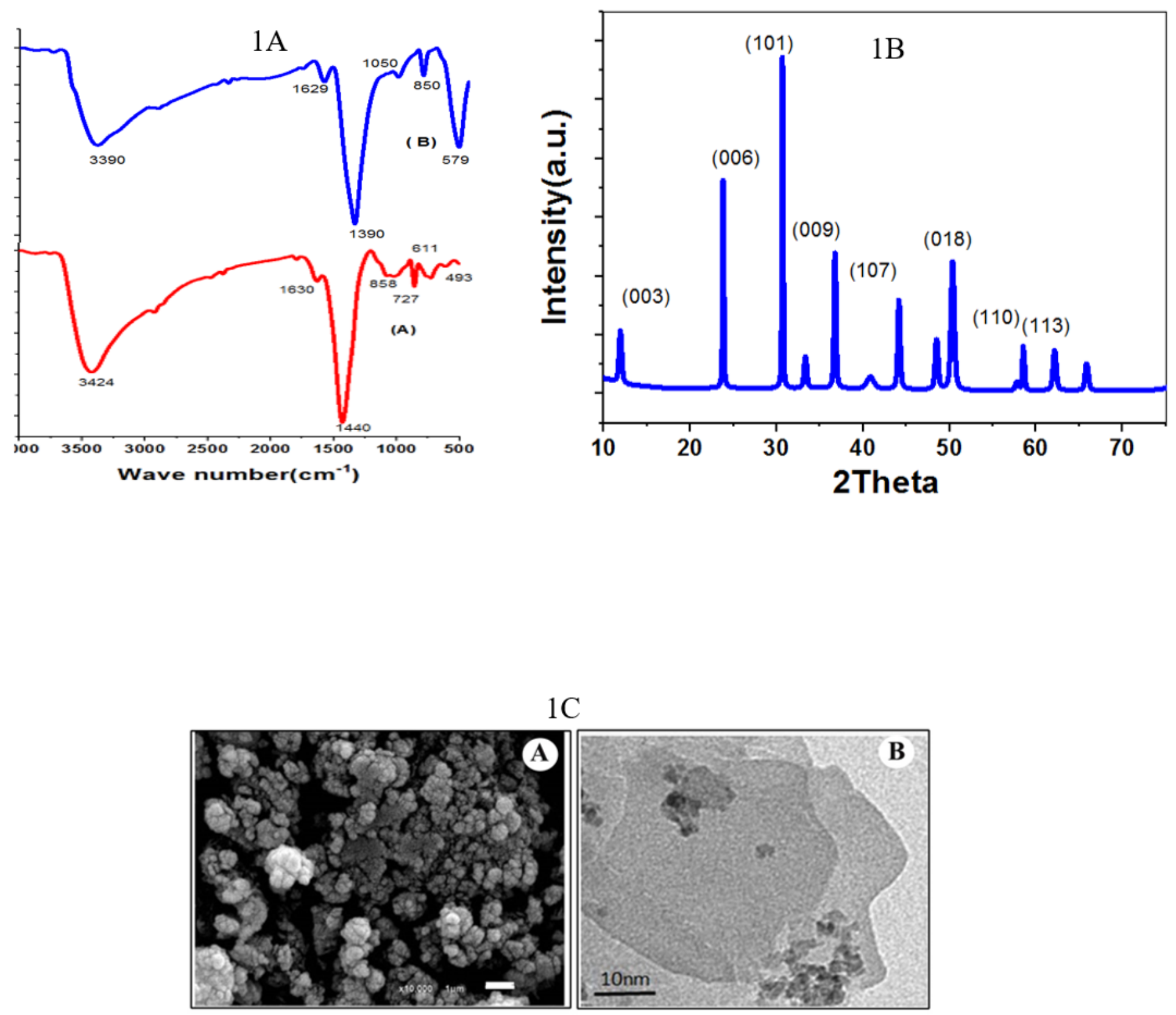

Figure 1

Characterization of LDH. (1A) FT-IR spectra of of Co-Cd-Fe LDH (A) and Co-Cd-Fe LDH composite with PbI2 (B), (1B) XRD patterns of Co-Cd-Fe LDH, (1C) FESEM of fabricated Co-Cd-Fe LDH (A) TEM of Co-CdFe LDH (B). 


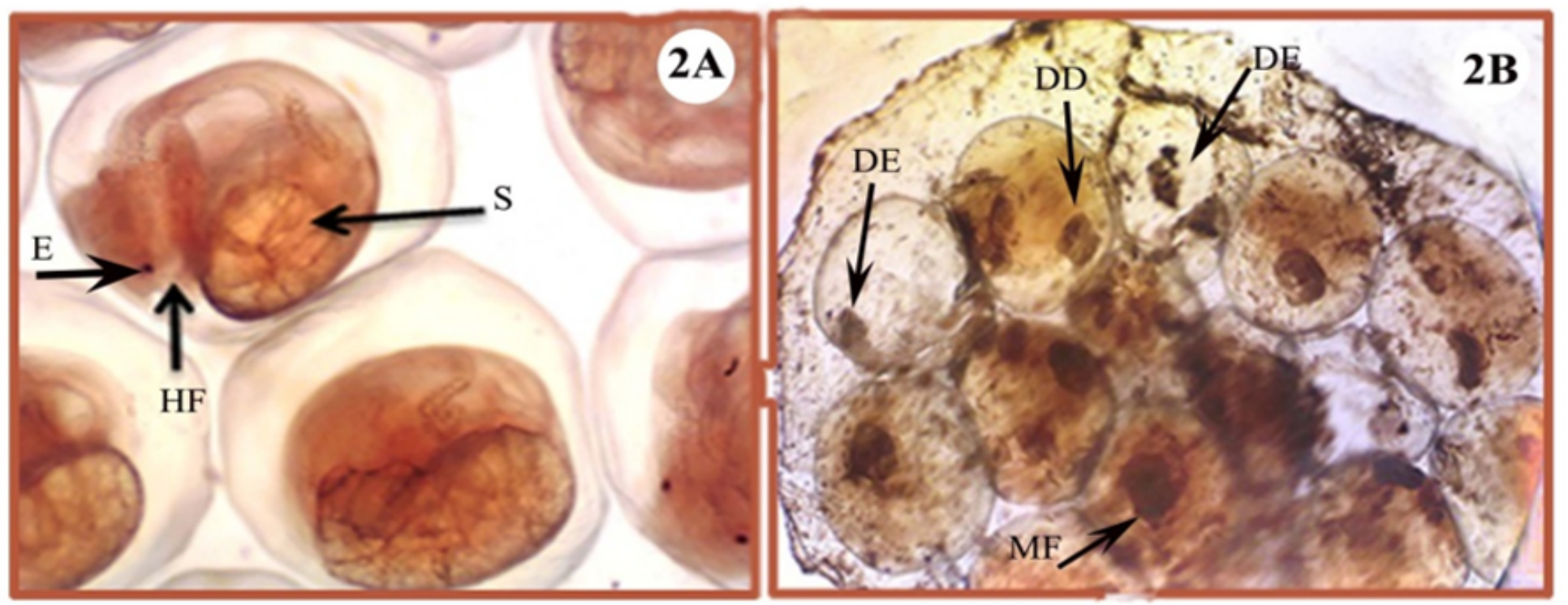

Figure 2

Morphological abnormalities in Biomphalaria embryos after exposure to Co-Fe-Cd LDH. (2A) Normal control embryos of seven-days-aged where the snails completely formed (E: eye; HF: head foot; S: shell). (2B) after exposure of the egg mass to LC25 Co-Fe-Cd LDH (DE: dead embryo; MF: malformed embryo; DD: development delay).
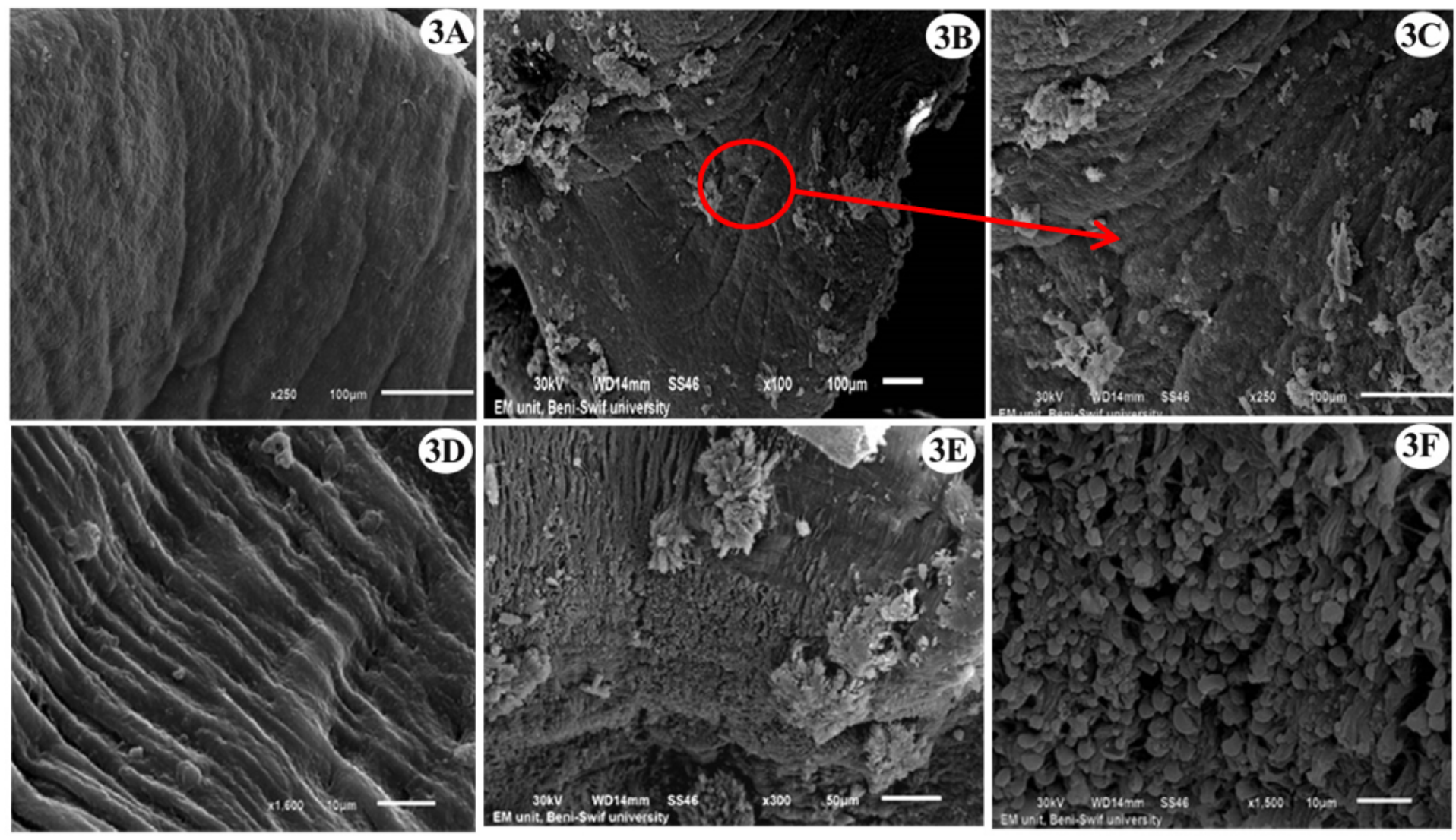

Figure 3 
Scanning electron micrographs (SEM) of B. alexandrina snails (soft part), (3A) Normal ultrastructure of foot with smooth and regular cilia, (3B) foot plantaris after exposure to Co-Fe-Cd LDH, the cilia became tangled and adherent, (3C) Higher magnification of 3B, (3D) Normal mantle showing smooth tegmental surface and microvilli, (3E) Mantle after exposed to Co-Fe-Cd LDH showing tortuosity, nipples, erosion and accumulation of LDH NMs in tegmental surface, (3F) Higher magnification of 3E.

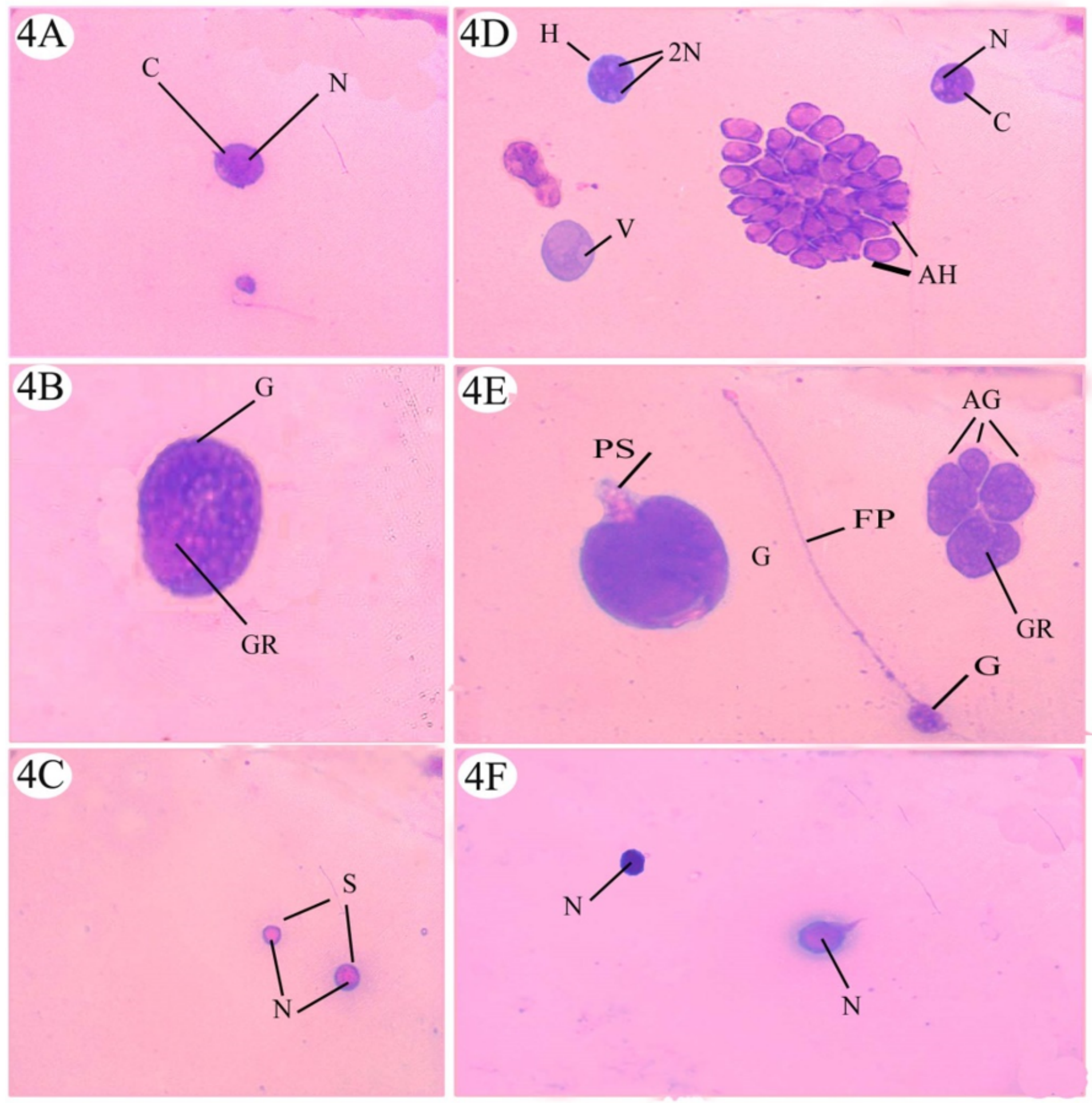

Figure 4 
Light micrographs show hemocytes of adult Biomphalaria alexandrina snails. 4A, hyalinocyte; 4B, granulocyte; 4C, small (x40), 4D, 4E and 4D show the abnormalities following exposure to LC25 of Co-FeCd LDH for 48h, 4D some hyalinocytes forming aggregations, two separate nuclei $(2 \mathrm{~N})$ and vacuoles $(\mathrm{V})$, $4 \mathrm{E}$ some granulocytes forming either pseudopodia (PP) or filopodia (FP) and aggregation (AG), 4F some hyalinocytes forming pseudopodia (PP). C: Cytoplasm, PS: Pseudopodia, G: Granulocyte, GR: Granules, H: Hyalinocyte, N: Nucleus, S: Round Small.

Caspase 3

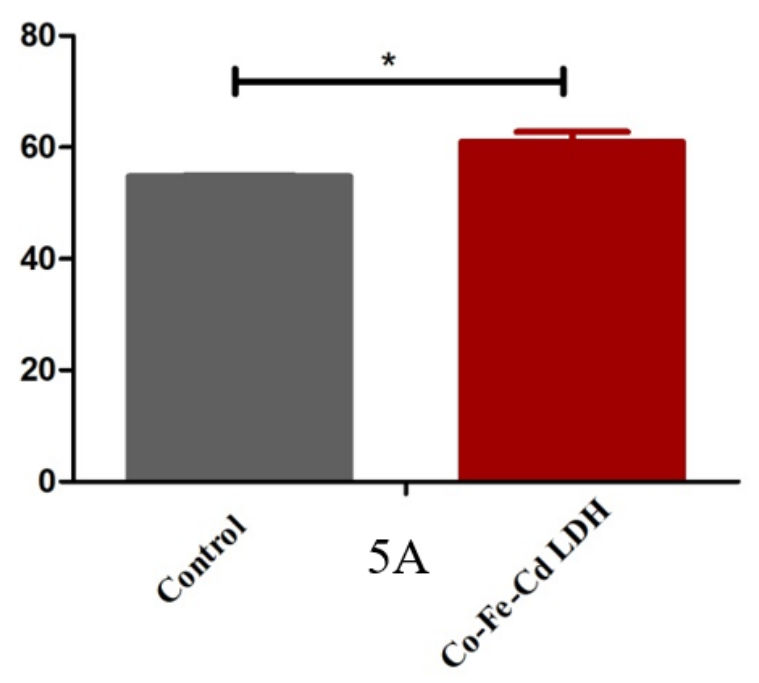

IL2

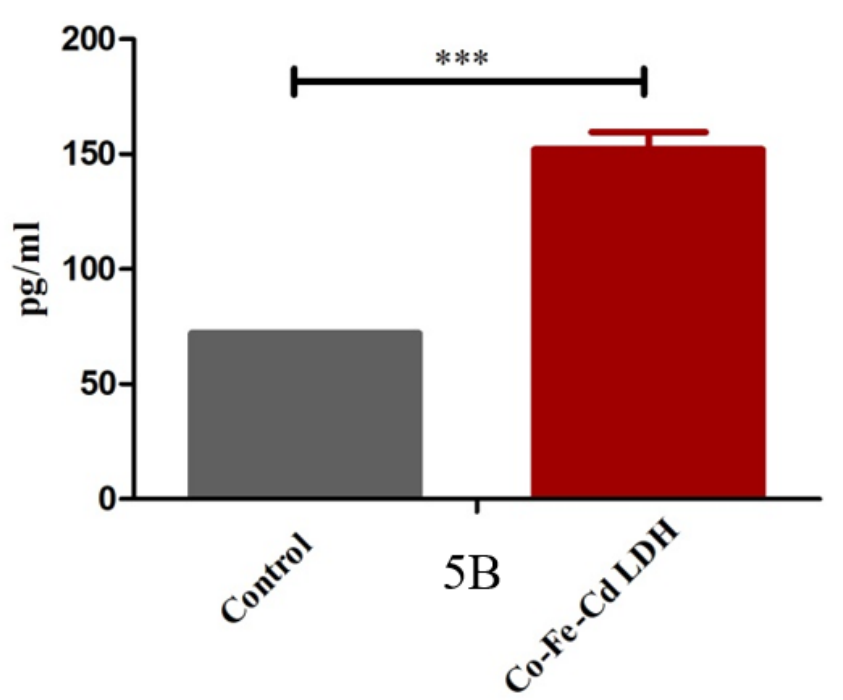

Figure 5

Effect of Co-Fe-Cd LDH on the expression of Caspase 3 and IL-2. All values presented as Mean \pm SE. *,,$* \star$ Significant difference as compared to control $(P<0.05, P<0.001)$ 

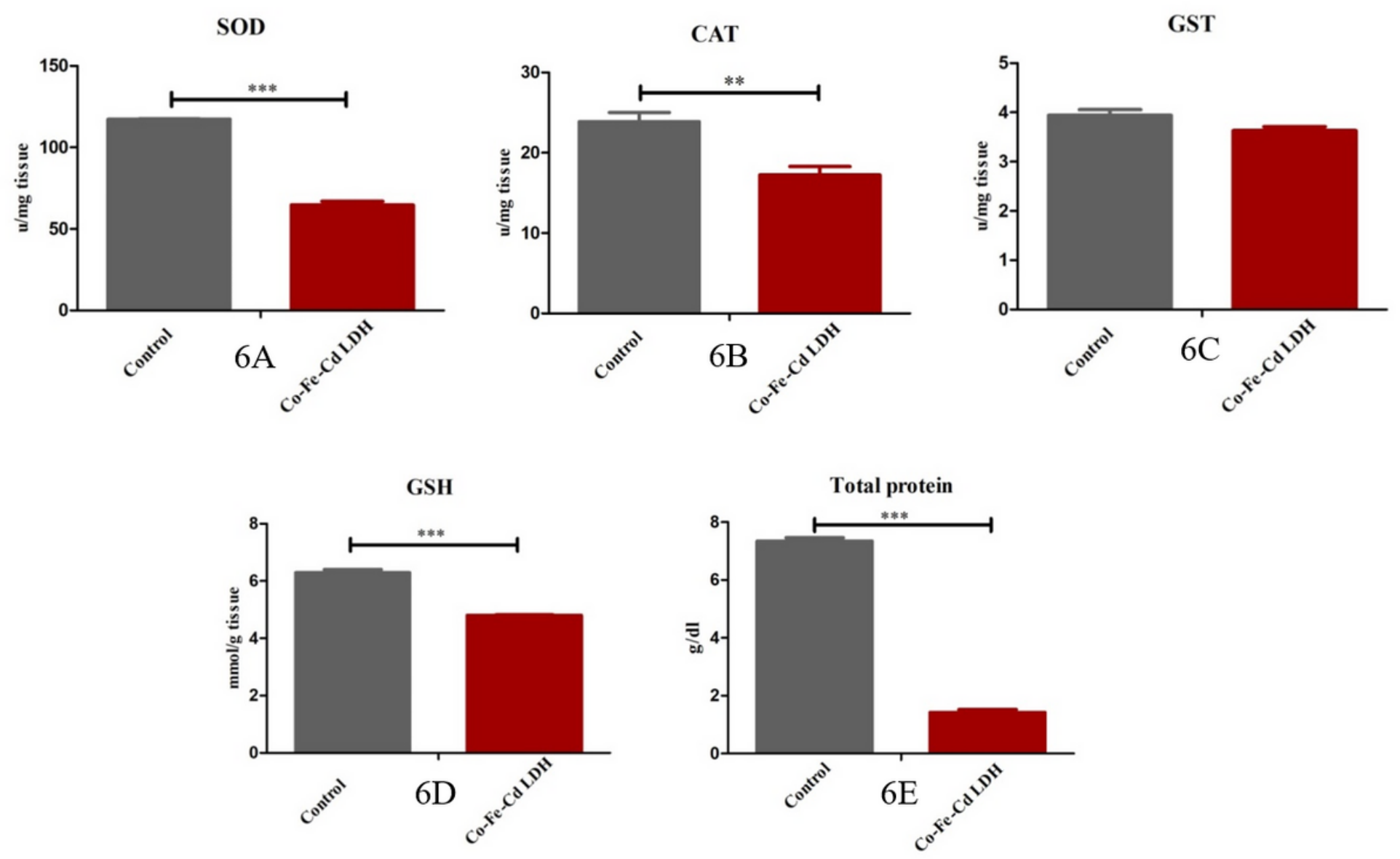

Figure 6

Effect of Co-Fe-Cd LDH on the levels of enzymatic and non-enzymatic parameters and total protein in

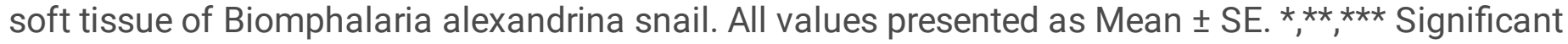
difference as compared to control $(P<0.05, P<0.01, P<0.001)$.
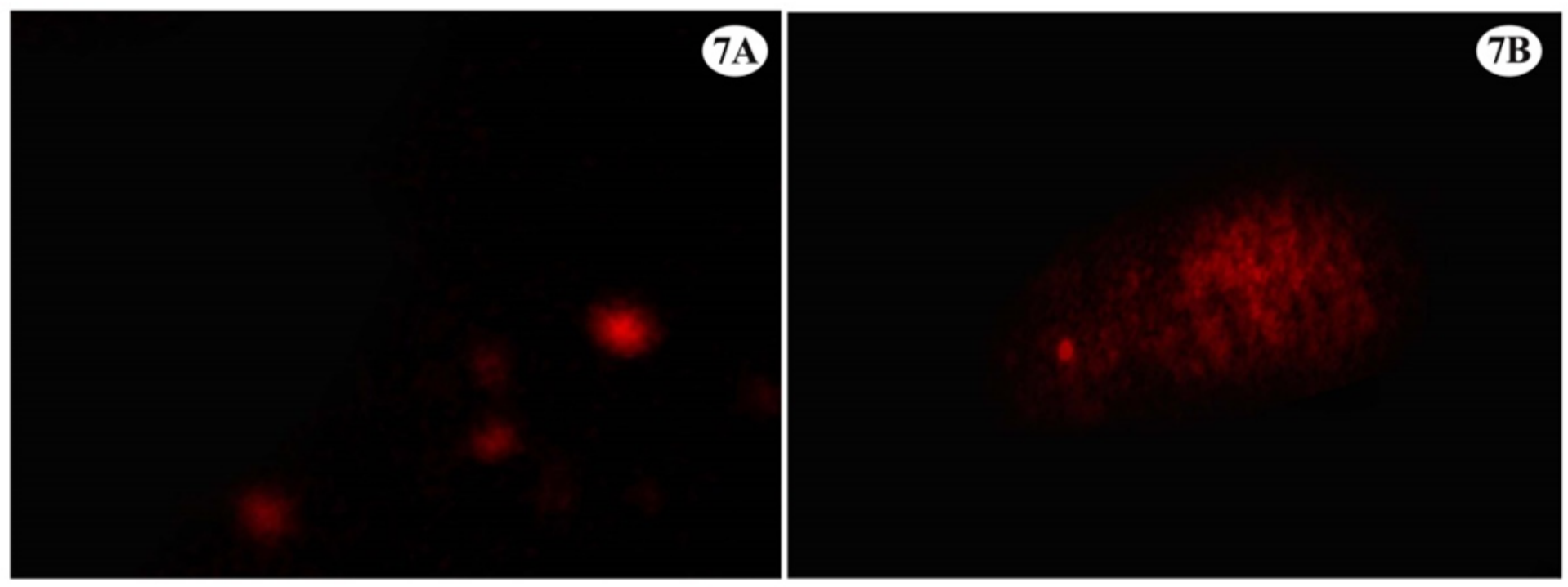

Figure 7 
Light micrograph shows the extent of DNA migration by comet assay. (7A) Control B. alexandrina; (7B) snails exposed to sublethal concentration of Co-Fe-Cd LDH for $48 \mathrm{~h}$ with high DNA migration $(p<0.01)$ than control snails.

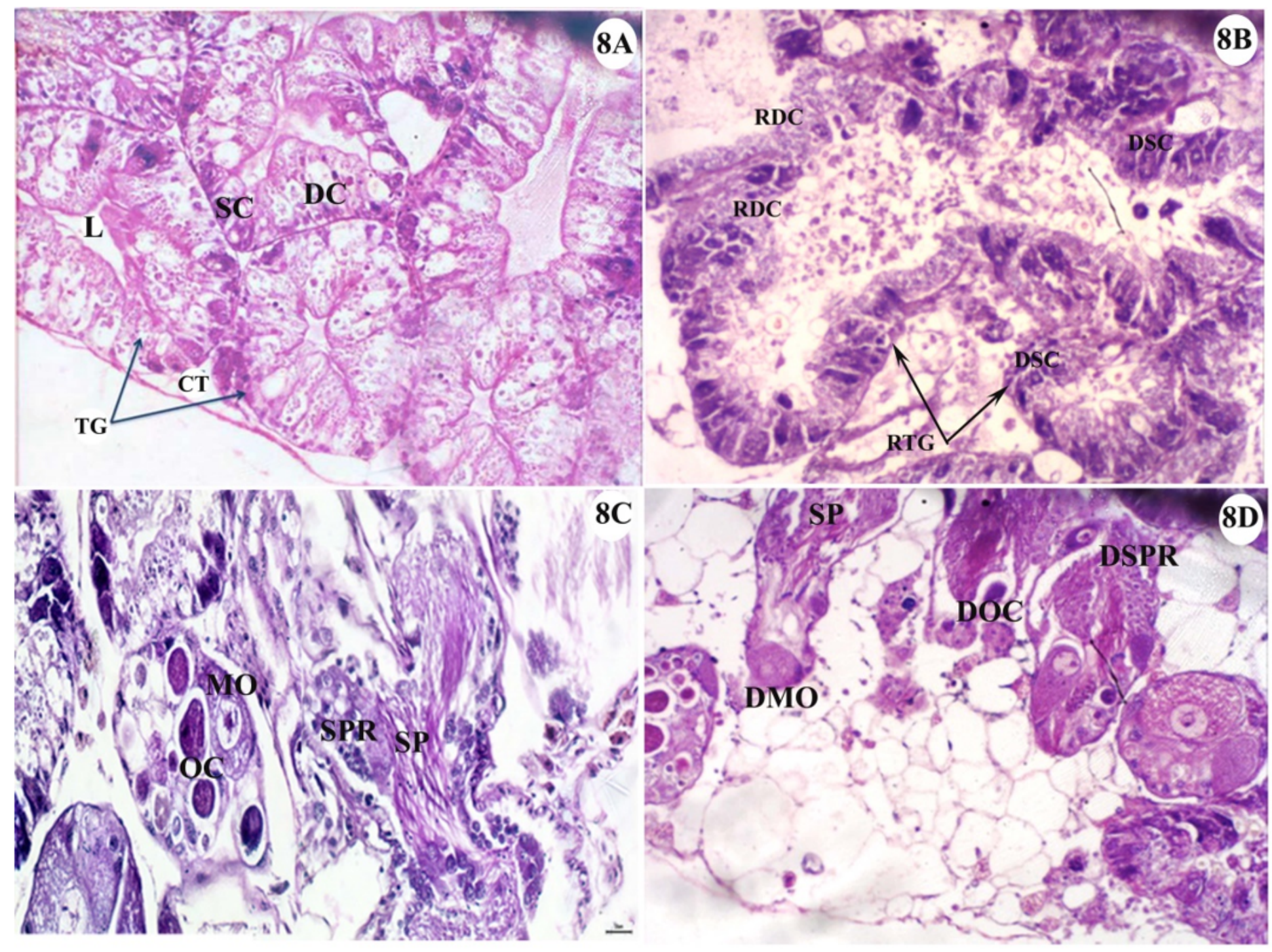

Figure 8

Light micrograph of the hermaphrodite and the digestive glands of $B$. alexandrina snails $(H \& E)(x 40)$ : (8A) normal digestive gland of B. alexandrina snails (8B) Snails exposed to LC25 of Co-Fe-Cd LDH (8C) Normal hermaphrodite gland of B. alexandrina snails (8D) Snails exposed to LC25 of LDH. MO: Mature ovum, OC: Oocytes, SP: Sperms, SP: Sperms, SPR: Spermatocytes, OC: Oocyte, DOC: Degenerated oocytes, DSPR: Degenerated spermatocytes. DC: Digestive cells, SC: Secretory cells, L: Lumen, TG: tubular gland, CT: Connective tissue, RDC: Ruptured digestive cells, DDC: Degenerated digestive cells, RTG: Ruptured tubular gland, RSC: Ruptured secretory cells. 